\title{
Geochemistry of natural waters of the Baydar valley (Crimean Peninsula)
}

\author{
Larisa A. Nichkova ${ }^{1}$, Dmitry A. Novikov ${ }^{2,3,}{ }^{*}$, Anatoliy V. Chernykh ${ }^{2}$, Fedor F. Dultsev ${ }^{2}$, \\ Galina A. Sigora ${ }^{1}$, and Tamara Yu. Khomenko ${ }^{1}$ \\ ${ }^{1}$ Sevastopol State University, the Chair of Technosphere Safety, Universitetskaya str., 33, Sevastopol \\ 299053, Russia \\ ${ }^{2}$ Trofimuk Institute of Petroleum Geology and Geophysics SB RAS, Laboratory of Hydrogeology of \\ sedimentary basins of Siberia, 630090 Koptyug ave. 3, Novosibirsk, Russia \\ ${ }^{3}$ Novosibirsk State University, Geological and Geophysical Department, 630090 Pirogov str. 1, \\ Novosibirsk, Russia
}

\begin{abstract}
The paper discusses the pioneering results of comprehensive hydrogeochemical studies of natural waters of the Baydar valley (southwestern parts of the Crimean Peninsula), whose major aquifers are confined to the upper Jurassic sediments (karst limestone) representing the most important hydrogeological feature of the study area. Fresh and ultrafresh waters of predominantly bicarbonate calcium composition with total mineralization in the range from 194 to $1137 \mathrm{mg} / \mathrm{dm}^{3}$ are most widespread in the region. The analyzed waters (surface, ground and artesian) differ significantly in chemical composition and their basic characteristics have been arranged in the following patterns: mineralization of $254-832 \mathrm{mg} / \mathrm{dm}^{3}$ and neutral $\mathrm{pH}$ (6.98-7.54) for artesian waters; higher mineralization level (up to $1137 \mathrm{mg} / \mathrm{dm}^{3}$ ) and wide variations of $\mathrm{pH}$ values (from 7.18 to 8.31 ) for ground waters; mineralization from 194 to $288 \mathrm{mg} / \mathrm{dm}^{3}$ and a slightly alkaline $\mathrm{pH}$ (between 8.02 and 8.04) for surface waters collected in the Chyornaya river basin and Chernorechensk reservoir. The studied waters display a unique spectrum of trace elements and REE distribution.
\end{abstract}

\section{Introduction}

There is growing worldwide research in recent years setting out to assess the water resources. Besides, there is a concern about the quality and pollution levels of drinking groundwater in a changing climate. According to the most optimistic predictions, the global mean annual air temperature will increase by at least two degrees Celsius by the beginning of the next century, regardless of human impact, triggering thereby vast and irreversible changes to the Earth's climate. Surges of heat, droughts, and other extreme weather events, concomitant with the rising sea level, are expected to be much more hazardous though, given a temperature rise by two degrees or more [1].

\footnotetext{
* Corresponding author: NovikovDA@ipgg.sbras.ru
} 
The ecological conditions and quality aspects of groundwater used for public drinkingwater supply are one of the most urgent concerns for the city of Sevastopol, aggravated by the problems of ever increasing number of tourists, along with the necesity to meet the current and future needs in drinking water, which also requires solving the tasks of ensuring social stability, improving health care and increasing life expectancy. The Baydar valley is located in the picturesque southwest region of the Crimean Peninsula within the Balaklava district of the Sevastopol city agglomeration. On the southern and eastern sides, the valley is adjacent to the main ridge of the Crimean mountains (Foros, At-Bash, Ai-Petri and others). The major groundwater resources of the study area are confined to the Upper Jurassic aquifer complex, which plays an important role, being associated with the main recharge areas for head water systems within three major hydrogeological structures: the Plain Crimea and Azov-Kuban artesian basins and hydrogeological folded region of megaanticlinorium of the mountainous Crimea.

This complex was studied in greatest detail within the Rodnikovskoe water intake in the Baydar valley. This paper presents results of the comprehensive hydrogeochemical studies of natural waters (artesian, ground and surface) conducted during October 2018, which encompassed a total of 25 water outlets (see Fig. 1 for their location scheme).

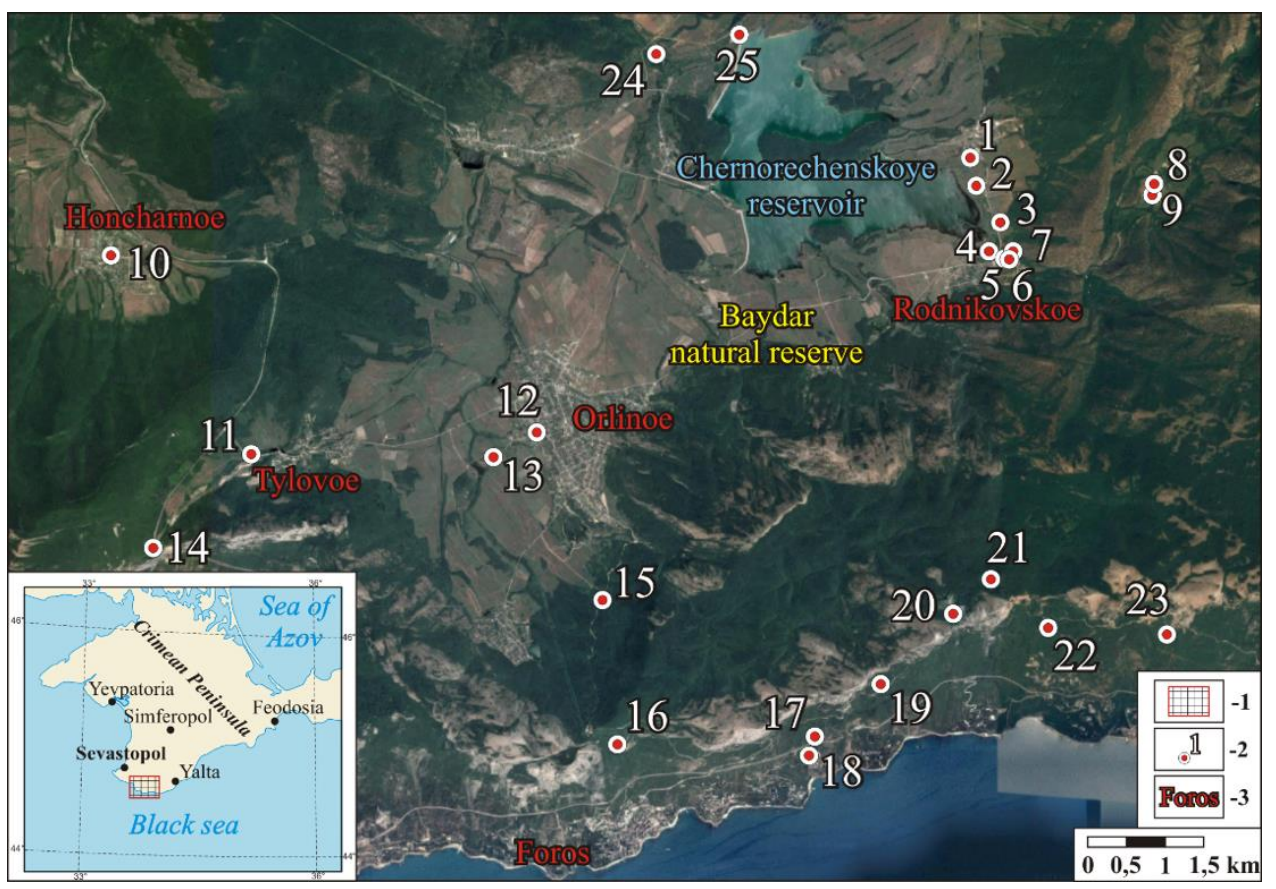

Fig. 1. Location of the studied water outlets within the Baydar valley and the mountain ranges rimming it. Artesian water: 1-6 - 6 wells of Rodnikovskoe groundwater deposit, springs 7 - Skel'sky (basic), 10 - Kara-Agach, 11 - Stranny, 12 - Varnaly fountain, 15 - Despit, 23 - Merdven-Kayasy); Groundwaters: 8 - Kolkhozny-southern, 9 - Kolkhozny-northern, 13 - Fuska-Chokrak, 14 - Laspi observation deck, 16 - in the vicinity of the Church of the Resurrection of Christ, 17 - Sanatornyupper, 18 - Sanatorny-lower, 19 - Kilse-Burun, 20 - Kuyu-Alan, 21 - Chertova Lestnitsa, 22 - Q044; Surface waters: 24 - Chyornaya river and 25 - Chernorechensk reservoir. 


\section{Results and discussion}

The water-bearing complex of Upper Jurassic sediments $\left(\mathrm{J}_{3}\right)$ is viewed as part of the lower (Mesozoic) aquifers floors and includes two aquifers: Middle-Upper OxfordianKimmeridgian $\left(\mathrm{J}_{3} \mathrm{O}_{2-3}-\mathrm{J}_{3} \mathrm{~km}\right)$ and Middle-Upper Tothonian deposits $\left(\mathrm{J}_{3} \mathrm{tt}_{2-3}\right)$, and partitioning them the Lower Tithonian aquiclude $\left(\mathrm{J}_{3} \mathrm{tt}_{1}\right)$. The Middle-Upper Oxfordian-Kimmeridgian aquifer comprises deposits of the Yailinskaya and Sukhorechensky Formations. The Yailinskaya Formation is divided into two subformations: the lower one comprises browngrey limestone with interbedded silt limestone, and lenses of sandstones and siltstones; the upper one consists of brown-grey limestone, with units of arenaceous and argillaceous limestones and marls. The Sukhorechensky Formation is composed of conglomerates with lenses of coarse sandstones and organogenic limestones. The Lower Tithonian aquiclude consists of deposits of the Deymen-Derin Formation, which, in turn, is divided into two subformations. The lower subformation is composed of flysch-like interbedding of grey clays and silt brown-grey detrital limestone. The upper subformation is composed of grey silty clays with nodules of siderite and intercalations of detrital limestone. The overrlying aquifer of Middle-Upper Tithonian sediments are represented by two Formations - the Kalafatlar and Baydar. The former is composed of polymictic conglomerates with the Yailinskaya limestone blocks. The latter is represented by different types of limestones. Results of our studies have revealed a great impact of anthropogenic factors on the composition of natural waters of the Baydar valley. The springs and water wells located in rural settlements (namely, the Varnala fountain in Orlinoe village and Stranny in Tylovoe village, water wells in Kolkhoznoye village) and in close proximity to roads (water wells near the Church of the Resurrection of Christ and Laspi observation deck) are found to be particularly susceptible to pollution. Fresh and ultra-fresh waters of predominantly bicarbonate calcium composition with TDS varying from 194 to $1137 \mathrm{mg} / \mathrm{dm}^{3}$ are widespread in the studied region (Fig. 2).

Artesian waters are characterized by TDS values from 254 (Well 53-A) to 832 (Stranny spring) $\mathrm{mg} / \mathrm{dm}^{3}$. The amounts of dominating calcium and bicarbonate ions vary from 58.1 to $176.4 \mathrm{mg} / \mathrm{dm}^{3}$ and from 144.1 to $400.0 \mathrm{mg} / \mathrm{dm}^{3}$, respectively. The concentrations of sodium and potassium range from 1.8 to $42.0 \mathrm{mg} / \mathrm{dm}^{3}$, magnesium - from 2 to $5 \mathrm{mg} / \mathrm{dm}^{3}$, chloride anions - from 3.4 to $39.0 \mathrm{mg} / \mathrm{dm}^{3}$ and sulfate - from 5 to $177 \mathrm{mg} / \mathrm{dm}^{3}$. The values of $\mathrm{pH}$ which vary from 6.98 to 7.54 (averaging 7.30 ) for these waters, are the lowest among the three identified groups. The second group includes groundwaters from the studied water wells.

Their TDS values vary from $242 \mathrm{mg} / \mathrm{dm}^{3}$ (Kilse-Burun) to $1137 \mathrm{mg} / \mathrm{dm}^{3}$ (in vicinity of the Church of the Resurrection of Christ). These are also dominated by calcium and bicarbonate, whose concentrations range from 50.3 to $212.4 \mathrm{mg} / \mathrm{dm}^{3}$ and from 147.1 to $588.2 \mathrm{mg} / \mathrm{dm}^{3}$, respectively. The concentrations of chloride are from $7.9-91 \mathrm{mg} / \mathrm{dm}^{3}$, sulfate - from 4 to $190 \mathrm{mg} / \mathrm{dm}^{3}$, the sum of sodium and potassium - from 9.0 to $89.4 \mathrm{mg} / \mathrm{dm}^{3}$, magnesium cations - from 2.6 to $42 \mathrm{mg} / \mathrm{dm}^{3}$. The $\mathrm{pH}$ values in these waters range from 7.18 to 8.31 (on average, 7.60). The value of surface water mineralization (Chyornaya river and Chernorechensk reservoirs) varies from 193 to $287 \mathrm{mg} / \mathrm{dm}^{3}$. The waters from the Chernorechensk reservoir are differentiated by bicarbonate calcium-sodium composition as compared with the Chyornaya river. The concentrations of calcium cations vary within a narrow range, from 44.2 to $48.3 \mathrm{mg} / \mathrm{dm}^{3}$, the sum of sodium and potassium - from 3.3 to $42.7 \mathrm{mg} / \mathrm{dm}^{3}$, magnesium - from 1.8 to $2.0 \mathrm{mg} / \mathrm{dm}^{3}$. The anions are dominated by bicarbonate, varying from 105.9 to $126.5 \mathrm{mg} / \mathrm{dm}^{3}$, chlorine - from 6.4 to $25.0 \mathrm{mg} / \mathrm{dm}^{3}$, sulfate- from 6.8 to $34 \mathrm{mg} / \mathrm{dm}^{3}$. The $\mathrm{pH}$ values $(8.02-8.04)$ vary only slightly. 


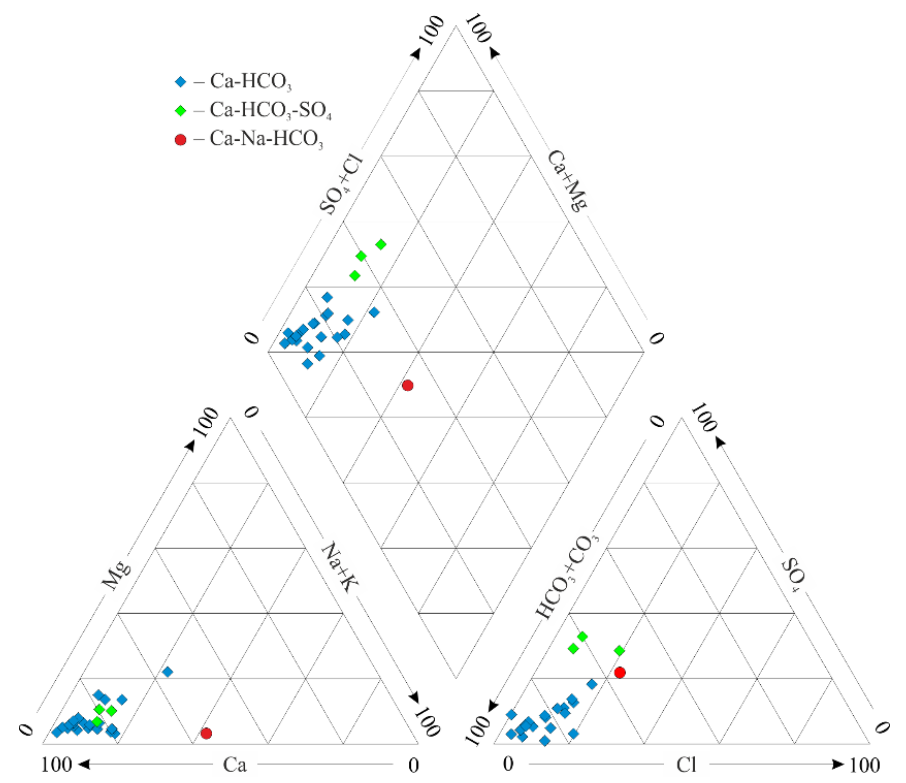

Fig. 2. Piper diagram of the groundwater composition in the Baydar valley.

Natural waters display intriguing spectra of trace elements and rare earth elements (REE) distribution in the suspended and water-dissolved forms, which are displayed as average concentrations for the artesian water, groundwater and surface water (Fig. 3). The analysis has shown that the concentrations of strontium (up to $1640 \mu \mathrm{g} / \mathrm{dm}^{3}$ ), iron (up to $546 \mu \mathrm{g} / \mathrm{dm}^{3}$ ), manganese (up to $356 \mu \mathrm{g} / \mathrm{dm}^{3}$ ), barium (up to $160 \mu \mathrm{g} / \mathrm{dm}^{3}$ ) and uranium (up to $1.4 \mu \mathrm{g} / \mathrm{dm}^{3}$ ) are enhanced in the micro-component composition of the studied waters. With increasing total mineralization (TDS), heavy metals (besides silica, strontium, barium) show the tendency to accumulate in the solution in the concentrations $\left(\mu \mathrm{g} / \mathrm{dm}^{3}\right)$ as follows: copper (up to 4), zinc (up to 18), cadmium (up to 1.2), vanadium (up to 1.1), chromium (up to 0.9 ), cobalt (up to 0.05 ), nickel (up to 0.3), molybdenum (up to 0.7), lead (up to 14.7), tin (up to 2.4).

Groundwaters in the water well located in the northern part of Kolkhoznoe village are characterized by higher levels of uranium (up to $1.4 \mu \mathrm{g} / \mathrm{dm}^{3}$ ), while background values do not exceed $0.3 \mu \mathrm{g} / \mathrm{dm}^{3}$. Among REE, the highest concentrations observed $\left(\mu \mathrm{g} / \mathrm{dm}^{3}\right)$ were: neodymium (up to 0.2), gadolinium (up to 0.07), europium (up to 0.06), dysprosium (up to 0.05), lanthanum (up to 0.02) and thulium (up to 0.017). The pattern of dominant REEs distributions in the suspended matter of natural waters defers significantly and is represented as follows $\left(\mathrm{mg} / \mathrm{dm}^{3}\right)$ : cerium (up to 0.07), lanthanum $(0.03)$, neodymium (0.028), ytterbium, and lutecium (up to 0.02). To date, a hydrogeochemical field of complex structure has been formed in the Baydar valley, which is greatly susceptible to anthropogenic factors, as is primarily manifested by the pattern of the most mineralized waters $\left(>500 \mathrm{mg} / \mathrm{dm}^{3}\right)$ distribution within the zone of influence of the existing road network along the Black Sea coastconnecting settlements. Composite hydrogeochemical anomalies have been established with respect to the levels of : cadmium $\left(>0.7 \mu \mathrm{g} / \mathrm{dm}^{3}\right)$, chromium $\left(>0.7 \mu \mathrm{g} / \mathrm{dm}^{3}\right)$, lithium $\left(>20 \mu \mathrm{g} / \mathrm{dm}^{3}\right)$, nickel $\left(>1 \mu \mathrm{g} / \mathrm{dm}^{3}\right)$, lead $\left(>10 \mu \mathrm{g} / \mathrm{dm}^{3}\right)$, strontium $\left(>1000 \mu \mathrm{g} / \mathrm{dm}^{3}\right)$, titanium $\left(>2.2 \mu \mathrm{g} / \mathrm{dm}^{3}\right)$, vanadium $\left(>0.5 \mu \mathrm{g} / \mathrm{dm}^{3}\right)$, zinc $\left(>10 \mu \mathrm{g} / \mathrm{dm}^{3}\right)$, rubidium $\left(>5 \mu \mathrm{g} / \mathrm{dm}^{3}\right)$ and other elements present in water. Most of these have a direct relationship with TDS of waters. The studied water outlets need to be additionally investigated at the end of the spring season, to reveal the geochemical signatures of natural waters after the rainy season and snow melting (i.e. meteoric and meltwater input analysis) 
in the highlands of the Ai-Petri yaila (plateau) and to confirm the identified hydrogeochemical anomalies.

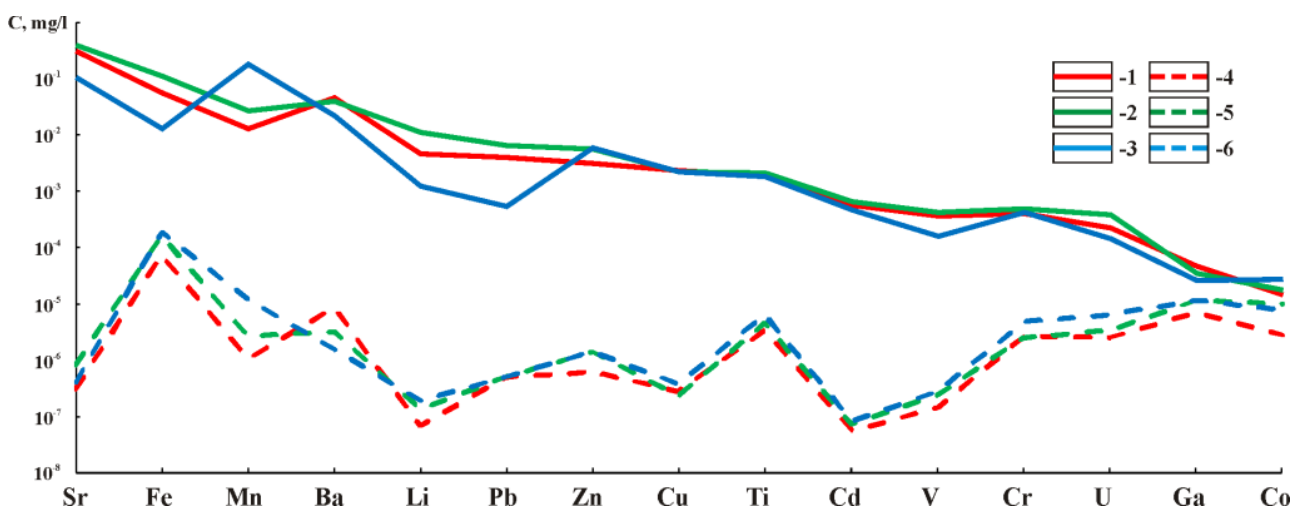

Fig. 3. Distribution spectrum of trace elements (1-3) and suspended matter (4-6) in natural waters within the Baydar valley. Waters: 1,4-artesian, 2,5-ground, 3,6-surface.

\section{Conclusions}

Summarizing the above, it should be noted that fresh and ultra-fresh waters of mainly bicarbonate calcium composition with the TDS value varying from 194 to $1137 \mathrm{mg} / \mathrm{dm}^{3}$ are widespread within the Baydar valley area. The studied water outlets fall into three groups: surface, ground and artesian waters. Among them, artesian waters appear to be the most protected from the anthropogenic influence have mineralization of $254-832 \mathrm{mg} / \mathrm{dm}^{3}$ and are characterized by neutral $\mathrm{pH}$ value (6.98-7.54). Groundwaters are characterized by higher mineralization (up to $1137 \mathrm{mg} / \mathrm{dm}^{3}$ ), and $\mathrm{pH}$ values have a wider range (from 7.18 to 8.31 ). Surface waters comprising the Chyornaya river and Chernorechensk reservoirs are characterized by mineralization from 194 to $288 \mathrm{mg} / \mathrm{dm}^{3}$ and are found to be slightly alkaline with low variations in $\mathrm{pH}$ values (8.02-8.04). Besides, the studied waters exhibit an intriguing spectrum of trace elements and REEs distribution. The contents of strontium, iron, manganese, barium and uranium in the micro-component composition of the studied waters show a visibly increasing trend. Among REEs, the highest concentrations are observed with respect to: neodymium, gadolinium, europium, dysprosium, lanthanum and thulium. In the suspended matter of natural waters, the distribution spectrum for the dominating REE concentrations (represented by cerium, lanthanum, neodymium, ytterbium and lutetium) differs significantly. The formation of the composition of natural waters within the Baydar valley and the mountainous ranges rimming it is greatly influenced by the anthropogenic activities, which is naturally manifested in the established complex of hydrogeochemical anomalies within the existing network of roads along the Black Sea coast and settlements (Tylovoe, Orlinoe and Kolkhoznoe).

The research was supported by the Russian Foundation for Basic Research and the city of Sevastopol within Scientific Project № 18-45-920032 p_a.

\section{References}

1. A.E. Raftery, A. Zimmer, D.M.V. Frierson, R. Startz, P. Liu, Less than $2{ }^{\circ} \mathrm{C}$ warming by 2100 unlikely, Nature Climate Chang, 7, 637-641 (2017) 